\title{
PROFIL STRATEGI PEMBELAJARAN BAHASA JEPANG DI SMA NEGERI 1 TEGALLALANG
}

\author{
I.W.J.Tanopa ${ }^{1}$, I. W. Sadyana ${ }^{2}$, G. S. Hermawan ${ }^{3}$ \\ ${ }^{123}$ Jurusan Pendidikan Bahasa Jepang, Universitas Pendidikan Ganesha, Singaraja \\ e-mail: wayan.julia.tanopa@undiksha.ac.id, wayan.sadyana@undiksha.ac.id, satya.hermawan@undiksha.ac.id
}

\begin{abstract}
Abstrak
Penelitian ini bertujuan untuk mendeskripsikan (1) strategi pembelajaran yang digunakan dalam proses pembelajaran bahasa Jepang di SMA Negeri 1 Tegallalang, (2) faktor-faktor yang mendasari penggunaan strategi pembelajaran dalam proses pembelajaran bahasa Jepang di SMA Negeri 1 Tegallalang, dan (3) kendala-kendala yang dihadapi dalam strategi pembelajaran bahasa Jepang di SMA Negeri 1 Tegallalang. Subjek penelitian ini adalah guru bahasa Jepang di SMA Negeri 1 Tegallalang. Pengumpulan data dilakukan dengan metode observasi, wawancara, dan dokumentasi, kemudian di analisis dengan metode deskriptif kualitatif. Hasil penelitian menunjukan bahwa (1) Strategi pembelajaran yang digunakan dalam proses pembelajaran bahasa Jepang di SMA Negeri 1 Tegallalang yaitu strategi drill, tanya jawab, dan pemberian tugas; (2) Faktor-faktor yang mendasari penggunaan strategi pembelajaran dalam proses pembelajaran bahasa Jepang di SMA Negeri 1 Tegallalang yaitu karakteristik siswa, dan kondisi siswa di kelas. (3) Kendala-kendala yang dihadapi dalam strategi pembelajaran bahasa Jepang di SMA Negeri 1 Tegallalang yaitu meningkatkan minat dan motivasi belajar siswa, dan kendala alokasi waktu.
\end{abstract}

Kata kunci: bahasa Jepang, profil, strategi pembelajaran

\section{要旨}

本研究は、テガララン第一高校における(1)日本語学習の過程において用いられてい る学習ストラテジー、(2)日本語学習戦略の利用の背景、(3) 日本語学習の障害を記述 することである。研究の対象は、テガララン第一高校の日本語教師である。データ 収集は、観察、インタビュー、記録の方法で行われ、これらは記述的な定性的方法 を使用して分析される。その結果、(1)用いられている学習戦略はドリル、質疑応答 、課題であることが明らかになった、(2)この学習戦略の背景としては、学習者の特 性や授業の状況が挙げられた、(3)学習戦略の実施に当たって直面する障害は、学習 者の学習意欲や学習時間の不足である。

\section{キーワード：日本語、概略、学習戦略}

\section{Pendahuluan}

Proses belajar mengajar akan berjalan lancar, efektif dan efisien dengan adanya interaksi yang baik antara komponen-komponen di dalam sistem pengajaran. Komponen-komponen ini saling mempengaruhi antara satu dengan yang lainnya. Guru bertindak melaksanakan proses pembelajaran agar tujuan dari proses tersebut dapat tercapai secara optimal. Oleh karena itu, guru diharapkan mengetahui dan memahami hakikat kegiatan belajar mengajar termasuk strategi dan metode pembelajaran. Untuk meningkatkan minat siswa dalam pembelajaran bahasa asing terutama bahasa Jepang, maka tidak lepas peran metode dan strategi guru ketika proses pembelajaran berlangsung. Peranan metode dan strategi guru dalam kegiatan pembelajaran yang optimal akan mengefektifkan proses pembelajaran sehingga hasil yang dicapai akan baik. Untuk menciptakan susasana belajar yang baik seorang guru harus mampu menggunakan metode dan strategi pembelajaran yang bervariasi.

Metode pengajaran adalah suatu pengetahuan tentang cara mengajar yang dipergunakan oleh guru atau instruktur kepada siswa di dalam kelas agar pelajaran itu dapat ditangkap, dipahami dan digunakan siswa dengan baik, (Abdul, 2013:21). 
Strategi pembelajaran adalah suatu kegiatan pembelajaran yang harus dikerjakan guru dan siswa agar tujuan pembelajaran dapat dicapai secara efektif dan efisien, Kemp (dalam Sanjaya, 2006). Hal ini perlu dilakukan oleh guru karena dapat mempermudah proses pembelajaran. Dengan adanya strategi yang jelas, proses pembelajaran akan terarah sehingga guru memiliki pedoman dan acuan bertindak yang sistematis dalam pelaksanaan pembelajaran.

Berdasarkan hal tersebut langkah untuk memiliki strategi ialah menguasai teknik-teknik penyajian atau biasanya disebut dengan metode pengajaran seperti Gouin Method dan Grammar Translation Method (GTM). Selain itu yang disebutkan tentang strategi di atas, membutuhkan seorang pendidik yang berkualitas serta diharapkan dapat mengarahkan anak didik menjadi generasi yang kita harapkan sesuai dengan tujuan dan cita-cita bangsa. Untuk itu, guru tidak hanya cukup menyampaikan materi pelajaran semata, akan tetapi guru juga harus pandai menciptakan suasana belajar yang baik, serta juga mempertimbangkan pemakaian strategi dalam mengajar yang sesuai dengan materi pelajaran dan sesuai pula dengan keadaan anak didik.

Strategi pembelajaran ada bermacam-macam dan setiap guru menerapkan strategi yang berbeda-beda dalam proses pembelajaran. Salah satunya di SMA Negeri 1 Tegallalang. Mata pelajaran bahasa Jepang di SMA Negeri 1 Tegallalang diajarkan mulai dari kelas X, XI, dan XII program Bahasa. Kelas yang menjadi subjek penelitian adalah kelas X Bahasa di SMA Negeri 1 Tegallalang, karena kelas tersebut terlihat bahwa pada awal semester pembelajaran, siswa kelas $X$ banyak yang kurang memahami bahasa Jepang karena baru pertama kali mendapatkan pembelajaran bahasa Jepang. Seiring berjalannya waktu strategi yang di terapkan guru mampu membuat siswa lebih memahami bahasa Jepang lebih cepat.

Berdasarkan observasi dan wawancara awal yang telah dilakukan di SMA Negeri 1 Tegallalang, penelitian terkait proses pembelajaran dilakuakan di kelas $X$ dikarenakan siswa kelas $\mathrm{X}$ baru pertama kalinya mengenal dan memperoleh mata pelajaran bahasa Jepang. Walaupun demikian, proses pembelajaran di kelas $X$ berlangsung dengan kondusif dan siswa siap untuk mengikuti pembelajaran di kelas. Hal ini dibuktikan dengan antusiasnya siswa untuk mengikuti pembelajaran dan mendengarkan penjelasan dari guru.

Profil yang akan dipaparkan adalah tentang strategi pembelajaran bahasa Jepang di SMA Negeri 1 Tegallalang. Penelitian ini akan menjelaskan tiga hal, yang pertama, tentang strategi pembelajaran yang digunakan dalam proses pembelajaran bahasa Jepang, yang kedua, akan menjelaskan tentang faktor-faktor yang mendasari penggunaan strategi pembelajaran dalam proses pembelajaran bahasa Jepang, dan yang ketiga, akan menjelaskan tentang kendala-kendala yang dihadapi dalam strategi pembelajaran bahasa Jepang.

\section{Metode}

\section{Pendekatan dan Jenis Penelitian}

Pendekatan yang digunakan dalam penelitian ini adalah deskriptif kualitatif. Pendekatan deskriptif kualitatif ini digunakan karena sesuai dengan tujuan penelitian yang mendeskripsikan data yang di ambil dari data yang bersifat ilmiah. Data dalam penelitian ini diperoleh melalui tiga cara yaitu melalui observasi, wawancara, dan dokumentasi.

Lokasi penelitian ini adalah di SMA Negeri 1 Tegallalang yang terletak di Jalan I Wayan Lunga, Tegallalang, Gianyar.

\section{Jenis dan Sumber Data}

Subjek pada penelitian ini adalah guru bahasa Jepang yang mengajar di SMA Negeri 1 Tegallalang yang berjumlah satu orang. Objek penelitian adalah strategi pembelajaran yang digunakan dalam proses pembelajaran, faktor-faktor yang mendasari penggunaan strategi pembelajaran dalam proses pembelajaran, dan kendala-kendala yang dihadapi dalam strategi pembelajaran bahasa Jepang di SMA Negeri 1 Tegallalang.

\section{Metode Pengumpulan Data}

Metode pengumpulan data yang digunakan dalam penelitian ini adalah observasi, wawancara, dan dokumentasi. 
Observasi ini dilakukan untuk memperoleh data mengenai, 1. Strategi pembelajaran yang digunakan dalam proses pembelajaran, 2. Faktor-faktor yang mendasari penggunaan stratetgi pembelajaran, dan 3. Kendala-kendala yang dihadapi dalam strategi pembelajaran.

Wawancara ini dilakukan untuk menanyakan hal-hal terkait profil strategi pembelajaran bahasa Jepang di SMA Negeri 1 Tegallalang. Pengumpulan data melalui wawancara dilakukan dengan menggunakan pedoman wawancara dan alat perekam suara digital. Data yang didapat kemudian dianalisis dan dideskripsikan secara kualitatif.

Dokumentasi digunakan untuk memperoleh data yang benar-benar valid dan memang diperlukan dalam penelitian. Dalam penelitian ini akan dikumpulkan data berupa dokumen yang terkait dengan administrasi pembelajaran (Silabus, RPP, bahan ajar atau materi yang digunakan, media pembelajaran, daftar penilaian dan lain-lain), dan foto dokumentasi kegiatan pembelajaran di dalam kelas.

\section{Teknik Analisis Data}

Setelah mengumpulkan data, langkah selanjutnya adalah menganalisis data. Menurut Sugiyono (2012 : 147) kegiatan dalam menganalisis data adalah mengklompokkan data berdasarkan variabel dan jenis responden, mentabulasi data berdasarkan variabel dari seluruh reponden, menyajikan data setiap varisabel yang diteliti, melakukan perhitungan untuk menguji hipotesis yang telah diajukan. Dalam penelitian ini digunakan langkah-langkah teknis analisis data yaitu 1) tabulasi data merupakan kegiatan menggabungkan semua data yang sudah diperoleh dari hasil observasi, wawancara, dan dokumentasi, 2) reduksi data merupakan proses pemilihan, pemusatan, penyederhanaan, dan peringkasan data mentah yang berhasil dikumpulkan selama fase pengumpulan data, 3) deskripsi data yakni seluruh data yang diperoleh melalui observasi dan wawancara di deskripsikan sesuai dengan kenyataan yang ada di lapangan. Pendeskripsian ini dilakukan berdasarkan sub masalah yang telah dikemukakan dalam rumusan masalah, 4) klasifikasi data merupakan proes pengelompokkan data dari data yang sudah tersusun rapi menjadi data yang tersusun berdasarkan kategori-kategori tertentu sesuai dengan tujuan penelitian, 5) penarikan kesimpulan ini dilakukan apabila semua data telah tersusun dengan rapi berdasarkan kategori-kategori tertentu kemudian dianalisis. Setelah proses tersebut barulah peneliti dapat menarik kesimpulan yang merupakan jawaban atas segala permasalahan penelitian.

\section{Hasil dan Pembahasan Hasil Penelitian}

Data ini diambil melalui observasi ketika proses belajar mengajar berlangsung di kelas oleh guru bahasa Jepang di SMA Negeri 1 Tegallalang. Observasi hanya dilakukan di kelas $X$ Bahasa karena subjek yang diteliti mengajar bahasa Jepang di kelas tersebut. Data hasil penelitian dan pembahasan Profil Strategi Pembelajaran bahasa Jepang di SMA Negeri 1 Tegallalang ini terdiri dari data hasil observasi dan data hasil wawancara sesuai dengan instrument yang digunakan dalam pengumpulan data.

\section{Pembahasan}

Berdasarkan hasil observasi pertama sampai keempat di kelas X Bahasa, dalam proses belajar mengajar bahasa Jepang guru menggunakan strategi pembelajaran yang bervariasi. Guru mengajar dengan menggunakan tahapan pembelajaran bahasa Jepang dasar. Tahapan yang pertama adalah Dounyuu dengan menggunkan bahasa Indonesia. Langkahlangkah yang dilakukan oleh guru yaitu mengulang materi pelajaran sebelumnya untuk mengetahui daya ingat siswa terhadap materi tersebut. Kemudian, setelah semua siswa ingat dan paham, guru melanjutkan pada materi pelajaran yang baru.

Tahapan kedua adalah Kihon renshuu. Pada tahap ini guru melatih kosakata dan pola kalimat baru kepasa siswa. Dalam memberikan latihan kosakata, guru menerapkan strategi drill kepada seluruh siswa, sekelompok siswa, dan salah satu siswa. Dalam pelaksanaanya, guru terlebih dahulu memperkenalkan kosakata yang terdapat pada buku pelajaran kepada siswa, kemudian siswa diberikan latihan pengucapan dengan pelafalan yang benar dari masing-masing koskata. Selain strategi drill, guru juga menggunakan strategi tanya jawab untuk mengetahui pemahaman siswa tentang materi yang diajarkan. Setelah seluruh siswa 
paham dengan kosakata yang telah diberikan, maka dilanjutkan pada pengenalan pola kalimat. Dalam pengenalan pola kalimat guru lebih banyak memberikan contoh secara lisan kepada siswa, sehingga guru juga dapat melakukan latihan pengucapan atau pelafalan yang tepat kepada siswa.

Pada tahap ketiga yaitu Ouyou renshuu. Guru lebih banyak melakukan tanya jawab tentang kegiatan yang telah dilakukan oleh siswa dan mmeriksa pemahaman siswa mengenai materi yang telah diajarkan seperti tanya jawab mengenai kosakata maupun kalimat yang telah diajarkan. Namun kegiatan latihan penerapan tidak berjalan sesuai dengan efektif karena guru lebih banyak menghabiskan waktu pada tahap latihan dasar dengan memastikan siswa sudah paham dengan materi yang diajarkan. Untuk mengoptimalkan proses pembelajaran, guru juga menggunakan strategi kelompok kecil, agar pada tahap latihan dasar siswa juga dapat berdiskusi dengan teman satu kelompoknya. Sehingga waktu yang dibutuhkan lebih singkat pada tahap latihan dasar.

Guru menggunakan metode pembelajaran Audiolingual Method dalam proses pembelajaran mengenal koskata dan pola kalimat baru secara berulang. Guru mengajarkan kosakata maupun pola kalimat baru secara lisan, siswa mengulangi apa yang diucapkan guru dalam bahasa Jepang. Sehingga siswa terbiasa berbicara dengan bahasa target. Pembelajaran di dalam kelas lebih didominasi dengan penggunaan metode pembelajaran GTM (Grammar Translation Method), guru menggunakan bahasa Indonesia dalam menjelaskan kosakata dan pola kalimat.

Dalam menggunakan metode terjemahan dan audiolingual method diterapkan suatu strategi permbelajaran, yaitu sebagai berikut.

\section{Drill}

Penggunaan strategi drill dalam proses pembelajaran terlihat dari observasi pertama sampai observasi keempat, dimana penerapannya sesuai dengan tahapan pembelajaran bahasa Jepang dasar yakni pada tahapan Kihon renshuu. Dalam penggunaan strategi drill guru melakukan kegiatan dengan cara memberikan latihan pengulangan pengucapan kosakata maupun pola kalimat baru secara berulang hingga siswa dapat melafalkan kosakata maupun kalimat dengan benar serta dapat mengingatnya. Dengan menggunakan drill siswa diberikan pemahaman secara bertahap, sehingga materi yang diberikan dapat melekat dalam pikiran siswa. Strategi drill lebih sering digunakan oleh guru ketika melakukan latihan mengenai kosakata dan pola kalimat baru, sehingga cocok untuk diterapkan dalam proses pembelajaran bahasa Jepang di kelas X Bahasa karena dapat mengembangkan keterampilan siswa dalam berbicara dan membuat siswa menjadi lebih aktif. Jenis latihan drill yang sering digunakan adalah repetition drill yang merupakan latihan mengulangi apa yang di ucapkan guru dengan tepat dan cepat (Asih, 2007). Contoh penerapan repetition drill yaitu.

Guru : "Ichi gatsu"

Siswa : "Ichi gatsu"

Guru: "Ni gatsu"

Siswa : "Ni gatsu"

Selain repetition drill, guru juga menerapkan jenis drill yang lain yaitu guru bertanya dalam bahasa Indonesia, kemudian siswa menjawab dengan menggunakan bahasa Jepang sebagai berikut.

Guru : "Dokter"

Siswa : "Isha"

Jenis kegiatan drill tersebut adalah question an answer drill, yang merupakan membuat jawaban dari pertanyaan yang diberikan (Asih, 2007). Dengan latihan ini siswa dilatih untuk menjawab pertanyaan dengan cepat dan tepat. Drill ini dilakukan pada seluruh siswa secara bersamaan maupun perorangan. Dengan menerapkan strategi drill ini siswa menjadi lebih aktif dalam proses pembelajaran serta dapat meningkatkan ingatan siswa terhadap materi yang diajarkan. Hal ini terlihat pada observasi pertama sampai observasi keempat bahwa setiap guru memberikan pertanyaan kepada seluruh siswa maupun perorangan, siswa mampu menjawab dengan tepat. 


\section{Tanya Jawab}

Berdasarkan hasil observasi yang telah dilakukan, penggunaan strategi tanya jawab diterapkan oleh guru dari observasi pertama sampai observasi keempat. Strategi Tanya jawab dilakukan pada seluruh siswa maupun salah satu siswa. Contoh tanya jawab yang dilakukan oleh guru kepada salah satu siswa ketika belajar mengenai pola kalimat di dalam kelas :

Guru : "Budi san, yume wa nandesuka?".

Siswa : "Kyoushi desu".

Guru: "Kyoushi wa indonesia go de nandesuka?"

Siswa : "Guru"

Strategi tanya jawab dapat membuat siswa menjadi lebih aktif, dapat mengontrol keadaan kelas, dan kemampuan berbicara siswa akan terlihat. Guru bertanya setelah menjelaskan pola kalimat di papan tulis untuk memastikan siswa sudah menyimak dengan baik apa yang dijelaskan oleh guru dan kemampuan siswa mengingat kosakata yang telah dipelajari sebelumnya. Selain itu, guru juga memberikan kesempatan kepada siswa yang ingin bertanya terkait hal-hal yang belum jelas atau dimengerti. Kegiatan tanya jawab ini dilakukan kepada seluruh siswa dengan menggunakan bahasa Indonesia maupun bahasa Jepang mengenai kosakata maupun kalimat yang masih tergolong sederhana yang telah dipelajari, dan bertujuan untuk mengukur pemahaman siswa terhadap penguasaan materi pelajaran dan mendorong siswa untuk bertanya kepada guru apabila terdapat hal-hal yang belum jelas atau dimengerti.

Berdasarkan hasil observasi dikelas, pelaksanaan strategi tanya jawab yang diterapkan berupa pertanyaan sederhana yang berkaitan dengan materi yang diajarkan. Siswa mampu menjawab pertanyaan dengan benar. Namun ada juga beberapa siswa yang masih salah dalam menjawab. Kesalahan siswa tidak disebabkan oleh pertanyaan yang tidak jelas, namun karena siswa kurang focus dalam menyimak materi pelajaran. Penggunaan strategi tanya jawab ini belum sampai pada tahap "information gap" yaitu strategi pembelajaran yang membentuk perbedaan atau kesenjangan informasi yang dimiliki oleh masing-masing siswa dan kesenjangan tersebut dapat dihilangkan dengan cara bertukar informasi yang dimiliki sesuai dengan ranah kognitif siswa sekolah dasar, yaitu pada ranah pengetahuan.

\section{Pemberian Tugas}

Penggunaan strategi pemberian tugas terlihat pada seluruh hasil observasi yang dilakukan. Pemberian tugas dilakukan ketika kegiatan pembelajaran telah selesai dan guru selalu mengoreksi tugas yang telah diberikan. Tugas atau pekerjaan rumah yang diberikan berupa kosakata maupun pola kalimat yang telah diajarkan sebelumnya. Hal ini bertujuan agar kemampuan siswa terhadap pemahaman materi yang telah dipelajari secara keseluruhan. Temuan ini sejalan dengan pendapat Roestiyah (2008) yang menyatakan bahwa tugas diberikan untuk mengetahui hasil belajar siswa dan dalam pemberian tugas perlu dilakukan evaluasi. Tugas tersebut dikerjakan oleh siswa secara individu. Pemberian tugas dapat merangsang siswa untuk aktif belajar baik secara individu atau berkelompok (Dharma, 2008).

Berdasarkan hasil observasi tersebut, guru menggunakan strategi drill dan tanya jawab dengan cukup baik, siswa terlihat antusias dalam mengikuti proses pembelajaran terbukti dengan semangat siswa dalam menjawab setiap pertanyaan dari guru baik ketika latihan drill maupun tanya jawab. Pemberian tugas juga cukup efektif mengingat alokasi waktu pembelajaran bahasa Jepang yang terbatas. Guru tidak pernah menerapkan strategi lagu dan permainan karena jumlah siswa yang cukup banyak dan karakteristik siswa sekolah dasar yang umumnya cenderung senang bermain dan suka berbicara akan menciptakan suasana kelas yang kurang kondusif. Strategi lagu dan permainan akan sangat bagus digunakan dalam pembelajaran apabila guru dapat memilih jenis permainan yang cocok untuk tingkatan sekolah dasar dengan mempertimbangkan jumlah siswa dalam kelas, umur siswa, topik yang diajarkan dan jenis pengelolaan kelas yang dibutuhkan (Padmadewi, 2012).

Adapun faktor-faktor yang mendasari penggunaan strategi pembelajaran adalah karakteristik siswa merupakan hal utama guru dalam menggunakan strategi drill, tanya jawab dan pemberian tugas dalam proses pembelajaran, dikarenakan dilihat dari minat siswa dalam belajar bahasa Jepang masih kurang, hal ini disebabkan karena siswa kelas X Bahasa di 
SMA Negeri 1 Tegallalang baru mengenal dan memperoleh pembelajaran bahasa Jepang sehingga terdapat beberapa siswa yang menganggap bahasa Jepang sulit dipelajari. Siswa di dalam kelas terdiri dari latar belakang kemampuan yang berbeda-beda dan tingkat kemampuan dalam menyerap materi pelajaran yang berbeda. Dengan berbagai perbedaan tersebut, maka seorang guru harus mampu untuk melibatkan siswa dalam proses pembelajaran tanpa harus membedakan siswa satu dengan yang lainnya. Strategi drill dan tanya jawab dilakukan oleh guru untuk menyampaikan materi pelajaran, selain dapat membuat siswa menjadi lebih aktif juga dapat melatih kemampuan berbicara siswa dan memahami materi pelajaran yang diberikan. Agar mampu memahami materi pelajaran yang diberikan, siswa harus mampu membaca kosakata dan kalimat dengan pelafalan yang benar, dan hal tersebut membutuhkan waktu yang cukup lama. Oleh karena itu, selain strategi drill dan tanya jawab, penggunaan strategi pemberian tugas juga dilakukan oleh guru.

Kondisi siswa di kelas juga menjadi faktor yang mendasari penerapan strategi drill, tanya jawab, dan pemberian tugas dalam proses pembelajaran bahasa Jepang. Kondisi kelas yang kondusif dan dapat dikontrol oleh guru merupakan tujuan utama dalam mencapai tujuan pembelajaran yang diinginkan. Apabila guru tidak mampu menciptakan suasana kelas yang kondusif, maka pembelajaran tidak akan berjalan sesuai dengan alokasi waktu maupun berdasarkan RPP (Rencana Pelaksanaan Pembelajaran) yang sudah dirancang sebelumnya.

Karena jumlah siswa di masing-masing kelas berjumlah 30 orang, guru tidak pernah menerapkan strategi lagu dan permainan dikarenakan dapat membuat siswa menjadi ribut dan tidak terkendali sehingga membuat suasana kelas menjadi tidak kondusif. Dengan penggunaan strategi drill dan tanya jawab, tidak hanya guru saja yang berperan melainkan keikutsertaan siswa dalam proses pembelajaran. Sedangkan strategi pemberian tugas diberikan agar siswa mampu memantapkan pemahaman materi pelajaran yang diberikan, baik secara individu maupun kelompok.

Meningkatkan minat belajar siswa merupakan kendala utama guru dalam mengajar bahasa Jepang. Motivasi belajar siswa adalah hal utama ketika ingin meningkatkan prestasi belajar siswa. Usaha-usaha yang dilakukan guru baik itu buku penunjang, fasilitas yang mendukung, media pembelajaran yang berkualitas serta strategi pembelajaran yang tepat, jika motivasi belajar siswa yang kurang maka usaha tersebut kurang berpegaruh pada siswa. Masih terdapat siswa yang pasif dalam proses pembelajaran walaupun sudah diberikan stimulus oleh guru. Karena tidak semua siswa berminat dalam mempelajari bahasa Jepang yang dianggap sulit untuk dipelajari. Untuk itu guru memberikan point atau nilai tambahan kepada siswa yang aktif di kelas dan kepada siswa yang menjawab pertanyaan guru dengan tepat. sehingga membuat siswa lebih termotivasi untuk belajar dan mendapatkan nilai tambahan dari guru.

Alokasi waktu pembelajaran bahasa Jepang yang diberikan sangat terbatas, sehingga menyebabkan guru tidak bisa menjelaskan materi sepenuhnya kepada siswa dan strategi pembelajaran yang digunakan juga tidak berjalan dengan efektif. Agar mampu memahami kosakata dan pola kalimat bahasa Jepang, siswa harus mampu untuk membaca kosakata dan pola kalimat dengan pelafalan yang benar, kemudian dilanjutkan pada pemahaman makna dari kosakata dan pola kalimat tersebut. Hal tersebut membutuhkan waktu yang cukup lama sehingga guru lebih sering memberikan tugas atau pekerjaan rumah untuk menjawab latihan soal yang terdapat pada buku penunjang. Jadi, alokasi waktu yang terbatas membuat kegiatan pembelajaran berlangsung kurang efektif.

Untuk mengatasi kendala-kendala yang ada dalam pembelajaran bahasa Jepang, guru di SMA Negeri 1 Tegallalang mengadakan sharing dengan guru di sekolah dasar lainnya untuk mengetahui langkah-langkah penerapan kurikulum 2013 dalam proses pembelajaran. Selain itu, untuk mengefisienkan waktu agar sesuai dengan RPP (Rencana Pelaksanaan Pembelajaran) yang telah dibuat, kemudian pada materi pelajaran kosakata dan pola kalimat sederhana guru sering memberikan latihan di sekolah yang berupa drill dan tanya jawab, sedangkan latihan soal yang terdapat pada buku penunjang menjadi tugas atau pekerjaan rumah. 


\section{Simpulan dan Saran}

Berdasarkan hasil penelitian dan pembehasan mengenai profil srategi pemebelajaran bahasa Jepang di SMA Negeri 1 Tegallalang dpat disimpulkan sebagai berikut.

(1) Strategi pembelajaran yang digunakan oleh guru yaitu startegi drill dan tanya jawab yang dilakukan di dalam kelas serta strategi pemberian tugas yang dilakukan ketika kegiatan pembelajaran telah berakhir.

(2) Faktor yang mendasari penggunaan strategi pembelajaran dalam kelas adalah karakteristik siswa dan kondisi di kelas, agar terciptanya susasana kelas yang kondusif sehingga pembelajaran sesuai dengan RPP yang telah dibuat.

(3) Kendala yang dihadapi guru dalam mengajar bahasa Jepang yaitu kendala pemilihan bahan ajar dang kendala alokasi waktu hal tersebut dapat diatasi dengan melakukan sharing untuk mengetahui langkah-langkah pembelajaran sesuai dengan kurikulum 2013 dan agar dapat mengefisienkan waktu, guru memberikan tugas atau pekerjaan rumah kepada siswa sehingga guru dapat menjelaskan materi pelajaran dengan maksimal.

Saran dari penelitian ini diharapkan guru bahasa Jepang di SMA Negeri 1 Tegallalang hendaknya mampu menerapkan strategi pembelajaran yang lebih bervariasi. Guru bahasa Jepang di SMA Negeri 1 Tegallang seharusnya mampu memanfaatkan penggunaan media pembelajaran lainnya, seperti menggunakan kartu bergambar agar siswa merasa tertarik untuk belajar dan tujuan pembelajaran yang diinginkan dapat dicapai. Perlunya peningkatan terhadap penelitian sejenis terkait dengan profil strategi pembelajaran bahasa Jepang agar dapat dimanfaatkan sebagai acuan dalam memahami strategi yang diterapkan oleh guru dalam mengajar bahasa Jepang.

\section{Daftar Pustaka}

Abdul, Majid. 2013. Strategi Pembelajaran Remaja. Bandung: Rosdakarya.

Armini, Ni Putu Yuli. 2018. Profil Strategi Pembelajaran Bahasa Jepang di Kelas 4 SD Saraswati Tabanan. Tersedia pada https://ejournal.undiksha.ac.id/index.php/JJPB/article/view/14949

Asih, Nur Saadah Fitri. 2007. "Efektivitas Penggunaan Metode Oral Drill Untuk Latihan Kemampuan Berbicara Bahasa Jepang". Jurnal Lingu Cultura, Volume 1, (hlm 57-63).

Dharma, Surya. 2008. Strategi Pembelajaran dan Pemilihannya. Jakarta: Departemen Pendidikan Nasional.

Padmadewi, Ni Nyoman. 2012. Strategi Pembelajaran Bahasa. Singaraja: Undiksha.

Roestiyah. 2001. Strategi Belajar Mengajar. Jakarta: Rineka Cipta.

Sanjaya, Prof. DR. H. Wina. 2006. Strategi Pembelajaran Berorientasi Standar Proses Pendidikan. Jakarta: Kencana Prenada Media Group.

Sugiyono. 2007. Metode Penelitian Pendidikan (Pendekatan Kuantitatif, Kualitatif dan R\&D). Bandung: Alfabeta. 